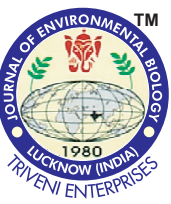

DOI : http://doi.org/10.22438/jeb/39/5/MRN-694

\title{
Removal of phenanthrene and cadmium from co-contaminated alkaline soil by carpet grass, Siam weed and winged bean
}

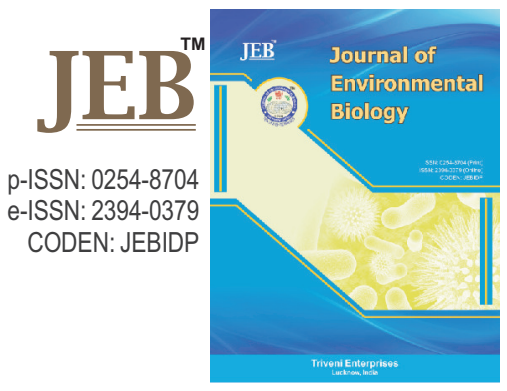

\section{Authors Info \\ K. Somtrakoon ${ }^{1 *}$ and W. Chouychai ${ }^{2}$ \\ ${ }^{1}$ Microbiology and Applied Microbiology Research Unit, Faculty of Science, Mahasarakham University, Kantharawichai, Mahasarakham-44150, Thailand \\ ${ }^{2}$ Biology Program, Faculty of Science and Technology, Nakhonsawan Rajabhat University, Nakhonsawan-60000, Thailand \\ ${ }^{*}$ Corresponding Author Email : khanitta.s@msu.ac.th}

Key words

Axonopus compressus Cadmium

Chromolaena odorata

PAHs, Phenanthrene

Psophocarpus tetragonolobus

Publication Info

Paper received : 13.07 .2017

Revised received: 07.11 .2017

Re-revised received : 18.11 .2017

Accepted: 09.02.2018

\begin{abstract}
Aim: Phytoremediation of soil co-contaminated with polycyclic aromatic hydrocarbon (PAH) and heavy metal is rarely reported. The aim of this study was to investigate the ability of carpet grass (Axonopus compressus), Siam weed (Chromolaena odorata) and winged bean (Psophocarpus tetragonolobus) to remove cadmium and phenanthrene concurrently from contaminated soil.

Methodology: Soil was spiked with phenanthrene alone or phenanthrene plus cadmium to give initial concentration of phenanthrene in soil with and without cadmium were 44.9 and $87.8 \mathrm{mg} \mathrm{kg}^{-1} \mathrm{dry}$ soil, respectively. Initial concentration of cadmium in soil spiked with phenanthrene plus cadmium was $6.2 \mathrm{mg}$ $\mathrm{kg}^{-1} \mathrm{dry}$ soil. Carpet grass, Siam weed and winged bean were planted separately in phenanthrene-spiked soil or phenanthrene and cadmium-spiked soil for 60 days. Growth of each plant, phenanthrene remaining in soil, cadmium remaining in soil, phenanthrene and cadmium in biomass of each plant were measured on day 30 and 60 of transplantation.
\end{abstract}

Results: Carpet grass, Siam weed and winged bean grew normally in soil spiked with phenanthrene alone or phenanthrene+cadmium over the 60-day experiment. The presence of plants did not result in cadmium removal, as the amount of this metal in soil remained unchanged after 60 days. Negligible amounts of phenanthrene and cadmium were accumulated by Siam weed, carpet grass and winged bean after 60 days. All three plants could increase the removal of phenanthrene from soil. Around $6.3-12.4 \%$ and 5.1 $27.1 \%$ of phenanthrene remained in planted soil in the absence or presence of cadmium in soil on day 60 , respectively.

Interpretation: The results s u g g e s t $t$ h a $t$ phytostimulation may be the main mechanism of phenanthrene removal from contaminated soil. The simultaneous removal of phenanthrene and cadmium in planted soil was not observe. A mild alkaline soil may decrease the accumulation of cadmium by plants.

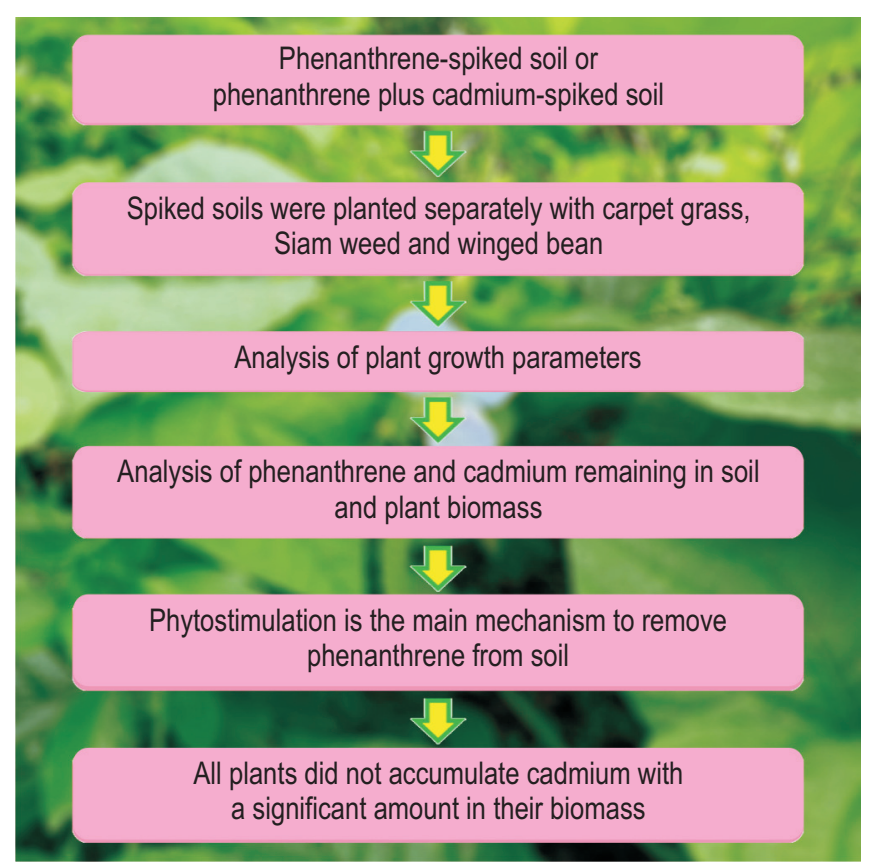




\section{Introduction}

A variety of sources are known to contribute to polycyclic aromatic hydrocarbon (PAH) and heavy metal contamination in the environment. Among these, the major sources are coal and wood burning, vehicle emissions and industrial activities such as petroleum refining, coke production and steel metallurgy (Hussain et al., 2015; Rachwał et al., 2015; Subramanian et al., 2015). Many PAH-contaminated sites also contain heavy metals such as arsenic, aluminium, cadmium, chromium, copper, lead, nickel and zinc. Moreover, the concentrations of total PAHs and metals may vary from site to site (Kuppusamy et al., 2016; Lyons et al., 2015; Rachwał et al., 2015). Removal of PAHs and heavy metals from the environment can be challenging. Phytoremediation has proved to be successful in the removing both PAHs (Somtrakoon et al., 2014 a, b; Xiao et al., 2015) and heavy metals (Khaokaew and Landrot, 2015; Tanhan et al., 2007; Waranusantigul et al., 2008) from contaminated soil. During phytoremediation, PAHs are mostly removed by competent rhizospheric microorganisms whose catabolic activities are stimulated by their association with the plant roots (Shahsavari et al., 2015; Tejeda-Agredano et al., 2013). In contrast, heavy metals are typically removed from contaminated sites by phytoaccumulation (Khaokaew and Landrot, 2015; Tanhan et al., 2007; Waranusantigul et al., 2008) or phytostabilization (Hu et al., 2013).

Success in phytoremediation depends on various factors such as type and concentration of contaminants, type of plants used and environmental variables. Among the latter, soil pH has been identified as a critical factor for plant growth (Willscher et al., 2017). Several soil series distributed in various parts of Thailand such as Takhli soil (pH 7.5-8.0), Kamphaeng Saen sub soil (pH 7.5-8.0), Tha Chin soil (pH 7.0-8.0) and Lop Buri soil (pH 7.0-8.0) are alkaline (Srithawat $\mathrm{Na}$ Ayuthaya, 1995). Soil alkalinity conditions have been reported to impede pollutant bioremediation (Anh et al., 2013). Soil pH may affect the bioavailability of metals and this may in turn affect their uptake by plants (Anh et al., 2013; McBride, 2002). In general, a lower soil pH renders metals more soluble and likely more bioavailable (Anderson and Nilsson, 1974). While it is expected that alkaline soil may pose a problem for phytoremediation of PAH and metal co-contaminated soils, very few studies have examined this.

Thus, the aim of the present study was to compare the ability of three plants from different families cultivated alone to remove phenanthrene and cadmium from alkaline soil contaminated with both pollutants. One of the plants used, winged bean, is widely cultivated as a food plant in Thailand, but it does not grow well in acidic soil with pH below 5.5 (National Park Board, 2013). Winged bean was reported to enhance anthracene and fluorene biodegradation in alkaline soil (pH 8.1) (Somtrakoon et al., 2014 b); however its propensity for metal accumulation is not known. The other two plants were carpet grass and Siam weed.
Carpet grass is a common lawn grass in Thailand and it can be grown in different soil types with varied $\mathrm{pH}$. Siam weed is also widely distributed throughout Thailand (Tanhan et al., 2007) and it was found to grow in areas with cadmium contamination which occur naturally in the zinc mining area in Mae Sot district, Tak province, Thailand (soil pH was 7.05-7.85) (Phaenark et al., 2009). Both Siam weed and carpet grass were reported to accumulate lead (at pH ranging from 7.05-7.85) and cadmium (at $\mathrm{pH}$ ranging from 5.50-6.50), respectively. To our knowledge, carpet grass has not been reported to enhance PAH removal, unlike Siam weed which has from soil (at pH 7.1) (Jampasri etal., 2016). To our knowledge, winged bean, Siam weed and carpet grass have never been tested before for the removal of both PAH and cadmium concurrently from alkaline soil.

\section{Materials and Methods}

Soil collection and analysis: Soil was collected from Khaorad Agricultural Station, Faculty of Agricultural Technology and Industrial Technology, Nakhonsawan Rajabhat University in January, 2016 during the dry season in Thailand. The soil was air dried at room temperature $\left(28-31^{\circ} \mathrm{C}\right)$ for $72 \mathrm{hrs}$ to constant dry weight before use. Concentration of total cadmium in soil and selected physical and chemical characteristics of the soil were analyzed at the Environmental Quality Examining Service Center, Faculty of Environment and Resource Studies, Mahasarakham University, Thailand. The soil contained $47.3 \%$ sand, $18.9 \%$ silt and $33.8 \%$ clay, and had a cationic exchange capacity of 15.1 $\mathrm{cmol} \mathrm{kg}^{-1}$ and a $\mathrm{pH}$ of 8.9. Soil was alkaline in nature. The background level of cadmium in form of $\mathrm{Cd}^{2+}$ was $1.9 \mathrm{~g} \mathrm{~kg}^{-1}$, while phenanthrene was not detected in this soil.

Spiking of soil with phenanthrene and cadmium $\left(\mathrm{Cd}^{2+}\right)$ : PAH and heavy metal used in this study was phenanthrene and cadmium. Phenanthrene-spiked soil was prepared according to the method described in the previous publication of Somtrakoon et al. (2015). The initial measured concentrations of phenanthrene in soil with and without cadmium were 44.9 and $87.8 \mathrm{mg} \mathrm{kg}^{-1}$ dry soil, respectively. Cadmium nitrate $\left[\mathrm{Cd}\left(\mathrm{NO}_{3}\right)_{2} \cdot 4 \mathrm{H}_{2} \mathrm{O}\right]$ (Asia Pacific Specialty Chemicals Limited, New South Wales, Australia; purity $99 \%$ ) soluble in distilled water was added to the phenanthrene-spiked soil to get a final concentration of about $5 \mathrm{mg} \mathrm{kg}^{-1} \mathrm{~d}$.wt. of soil in each batch of one $\mathrm{kg}$ soil. The measured concentration of cadmium $\left(\mathrm{Cd}^{2+}\right)$ in soil at the beginning of the experiment was $6.2 \mathrm{mg} \mathrm{kg}^{-1} \mathrm{~d}$.wt.

Plant preparation: Naturally grown plants of Siam weed were collected from a field which was previously used for farming in Chumsang District, Nakhonsawan Province, Thailand. The plants were transported to laboratory and were grown in noncontaminated soil in a nursery for one week. Carpet grass plants were purchased from a retail store in Nakhonsawan District, Nakhonsawan Province, Thailand and plants of similar weight and height were used in the phytoremediation experiment. 
Finally, seedlings of winged bean (commercial seeds of Chuayongseng Ltd., Bangkok, Thailand) were prepared by immersing them in distilled water before planting the seedlings into the soil. The date of seedling transplantation was considered day 0 of the experiment.

Pot experiment: Phytoremediation experiments were performed in the early summer of 2016 following the protocol described in the previous publication of Somtrakoon et al. (2015). Each of experimental pots contained one $\mathrm{kg} d$.wt. of soil spiked with either phenanthrene+cadmium or phenanthrene alone. The spiked soils were separately planted with carpet grass, Siam weed or seedlings of winged bean. The pots containing unspiked soil and planted with one of carpet grass, Siam weed or winged bean were set for plant growth. The other two pots were soil spiked with phenanthrene+cadmium or phenanthrene alone but without any plants for measuring PAH loss under plant-free conditions. Five independent replicates of each treatment were prepared in a completely randomized design. Each pot was watered regularly with distilled water to maintain the water holding capacity of soil at approximately $60 \%$ during 60 -day experiment.

On day 30 , soil and plant samples were collected from the first set of 55 experimental pots. From each pot, one gram d.wt. of soil was collected for analysis of phenanthrene concentration by GC-MS and another two grams of soil were collected for analysis of cadmium concentration. The plant from each pot was used to measure the length, fresh weight and dry weight of shoots and roots and chlorophyll a, chlorophyll b and total chlorophyll contents in leaves. Chlorophyll contents in plant leaves were analyzed according to the method described in the previous publication of Huang et al. (2004). On day 60, another set of 55 pots were subjected to various measurements as above. In addition, samples of plant tissues were sent for analysis of phenanthrene and cadmium contents. Extractions of phenanthrene from soil and plant tissues were done by soxhlet apparatus, as well as analysis by GC-MS were done according to the condition for PAH separation which was described by Somtrakoon et al. (2015).

Cadmium $\left(\mathrm{Cd}^{2+}\right)$ analysis: Two gram dry weight of soil and one gram dry weight of whole plant sample from each treatment were collected at the end of the experiment (60 days) to analyze the concentration of $\mathrm{Cd}^{2+}$ in soil and plant biomass. Soil and plant samples were subjected to extraction according the method described by Land Development Department, Thailand (2010). Cadmium content was analyzed by atomic absorption spectroscopy at the Environmental Quality Examining Service Center, Faculty of Environment and Resource Studies, Mahasarakham University. The detection limit of cadmium analysis was $0.5 \mathrm{mg} \mathrm{kg}^{-1}$.

Statistical analysis: Plant growth parameters and the amount of phenanthrene remaining in soil were expressed as means \pm SE.
One-way ANOVA was used to assess statistical significance among treatments for plant growth and phenanthrene biodegradation. Subsequent multiple comparisons of means were performed by the LSD method. Considering significance at $p<0.05$.

\section{Results and Discussion}

PAHs and metals are often found together in the environment. Remediation efforts must be taken this into account. However, most of the phytoremediation studies have focused on either PAH or metal remediation, but not both. The present study examined three plants that might be able to tolerate metals while enhancing PAH removal from PAH and metal co-contaminated alkaline soil. In this study, the overall growth of winged bean, Siam weed and carpet grass appeared normal in phenanthrene+ cadmium-spiked alkaline soil. The presence of phenanthrene or phenanthrene+cadmium in soil did not adversely affect the shoot growth of carpet grass and winged bean (Table 1). For shoot growth of plant, the shoot fresh weights and shoot dry weights of carpet grass and winged bean in soil spiked with phenanthrene were not significantly different from those of plants grown in soil spiked with phenanthrene+cadmium on both 30 and 60 days of experiment. In comparison, the shoot lengths of carpet grass grown in soil spiked with phenanthrene and phenanthrene+ cadmium ( 57.6 and $48.8 \mathrm{~cm}$, respectively) were longer than that of plants grown in unspiked soil $(23.6 \mathrm{~cm})$. In contrast to carpet grass, growth of Siam weed shoots was decreased in the presence of phenanthrene or phenanthrene+cadmium in soil. The fresh and dry weights of Siam weed shoots on day 60 were 10.3-14.0 $\mathrm{g}$ and 1.76-2.39 $\mathrm{g}$ in the presence of phenanthrene and phenanthrene+cadmium in soil, respectively. In comparison, the shoot fresh and dry weights of Siam weed grown in the absence of any phenanthrene or cadmium were 22.9 and $5.61 \mathrm{~g}$, respectively (Table 1).

Table 2 shows the results of root growth of carpet grass, Siam weed and winged bean in soil spiked with phenanthrene or phenanthrene+cadmium. The root of carpet grass grown in phenanthrene-spiked soil for 60 days was longer than that of plant grown in unspiked soil or phenanthrene+cadmium spiked soil. In contrast, the roots of winged bean grown in unspiked soil or soil spiked with phenanthrene+cadmium for 60 days were longer than that of plant grown in phenanthrene-spiked soil. However, the differences in root lengths for both plants grown under different treatments were not statistically significant. For Siam weed, none of the experimental treatments affected the root length as compared to the unspiked control. The root fresh weight and root dry weight of carpet grass grown in phenanthrene-spiked soil for 60 days were higher than those of plant grown in unspiked soil or soil spiked with phenanthrene+cadmium, but the differences were not statistically significant (Table 2). Similarly, the root fresh weight and root dry weight of winged bean grown for 60 days in soil spiked with phenanthrene+cadmium were higher than those 
of plant grown in unspiked soil or soil spiked with phenanthrene. Again, the differences were not statistically significant (Table 2). The root fresh weight of Siam weed grown for 60 days in unspiked soil and soil spiked with phenanthrene or phenanthrene+ cadmium were around $1.0-1.4 \mathrm{~g}$. The values were not statistically significantly different from one another. In contrast, the root dry weight of Siam weed grown in soil spiked with phenanthrene+cadmium $(0.08 \mathrm{~g})$ was significantly lower than that of plant grown in phenanthrene-spiked $(0.25 \mathrm{~g})$ or unspiked soil $(0.14 \mathrm{~g})$.

Also, the presence of phenanthrene or phenanthrene+ cadmium in soil did not adversely affect the chlorophyll contents in leaves of carpet grass, Siam weed and winged bean (Table 3). The contents of chlorophyll a, chlorophyll b, total chlorophyll and ratio of chlorophyll $a$ and $b$ of these plants grown in soil spiked with phenanthrene or phenanthrene+cadmium were not significantly different from those of plants grown in unspiked soil on both days 30 and 60 of experiment. This is not surprising because these plants are found throughout Thailand and they may have adapted to growth in various soil types, perhaps with different contaminants.

This study found that soil cropped separately with winged bean, Siam weed and carpet grass exhibited improved phenanthrene removal either in the presence or absence of cadmium in alkaline contaminated soil compared to unplanted soil. In unplanted soil without cadmium, the percentage of phenanthrene remaining on days 30 and 60 were 97.6 and $52.1 \%$, respectively (Table 4). Phenanthrene removal increased on day 30 in soil without cadmium but planted with carpet grass, Siam weed or winged bean in that the percentage of phenanthrene remaining were $59.0,45.5$ and $7.9 \%$, respectively. The results showed that winged bean removed phenanthrene at the fastest rate and to the highest extent in this soil. By day 60 , high amount of phenanthrene was removed from this soil by all three plants. In particular, lower percentage of phenanthrene remained in soil planted with carpet grass $(6.6 \%)$ and Siam weed (6.3\%) as compared to winged bean (12.4\%) (Table 4). In soil without plants, $52.1 \%$ of phenanthrene remained on day 60 .

The percentage of phenanthrene remaining in cadmiumspiked unplanted soil on day 30 was $60.9 \%$, while that in soil planted with carpet grass, Siam weed and winged bean were $35.5,31.4$ and $23.8 \%$, respectively. By day 60 , more phenanthrene was removed, such that the amount remaining in unplanted soil was not significantly different from those in planted soil. The percentage of phenanthrene remaining in cadmiumspiked soils was around 5.1-27.1\% (Table 4). Of the three plants, winged bean led to the largest percentage of phenanthrene removal in this cadmium-spiked soil.

The alkalinity condition has been reported to limit PAH remediation in several studies (Ke et al., 2003; Bentancur-Galvis et al., 2006). Ke et al. (2003) reported that remediation of pyrenecontaminated sediment planted with Kandelia candel for six months was inhibited under alkaline conditions. In the present study only $34.9 \%$ of pyrene was removed from contaminated sediment at $\mathrm{pH}$ 8.70-8.95, while $70.9 \%$ of pyrene was removed at pH 6.56-7.05 (Ke et al., 2003). In current study, the 3 plants were found to accumulate negligible amounts of phenanthrene in their tissues (Table 5). Only 1.0 and $1.2 \mathrm{mg}$ cadmium $\mathrm{kg}^{-1} \mathrm{dry}$ plant were detected in the whole plant of Siam weed and winged bean, respectively, grown for 60 days in phenanthrene+cadmium spiked soil. Cadmium was not detected in carpet grass biomass. The amount of cadmium remaining in soil planted with carpet grass, Siam weed and winged bean were not significantly different from those in unplanted soil. The amount of cadmium

Table 1: Shoot growth parameters of three plants grown in soil spiked with phenanthrene or phenanthrene plus cadmium for 60 days

\begin{tabular}{|c|c|c|c|c|c|c|}
\hline \multirow[t]{2}{*}{ Plant } & \multicolumn{3}{|c|}{ Day 30} & \multicolumn{3}{|c|}{ Day 60} \\
\hline & $\begin{array}{l}\text { Shoot length } \\
\text { (cm) }\end{array}$ & $\begin{array}{l}\text { Shoot fresh } \\
\text { weight }(\mathrm{g})\end{array}$ & $\begin{array}{l}\text { Shoot dry } \\
\text { weight (g) }\end{array}$ & $\begin{array}{l}\text { Shoot length } \\
\text { (cm) }\end{array}$ & $\begin{array}{l}\text { Shoot fresh } \\
\text { weight }(g)\end{array}$ & $\begin{array}{l}\text { Shoot dry } \\
\text { weight }(g)\end{array}$ \\
\hline \multicolumn{7}{|l|}{ Carpet grass } \\
\hline Unspiked soil & $7.7 \pm 0.3^{\mathrm{a}}$ & $0.3 \pm 0.1^{a}$ & $0.04 \pm 0.00^{\mathrm{a}}$ & $23.6 \pm 2.2^{b}$ & $2.5 \pm 0.5^{\mathrm{a}}$ & $0.43 \pm 0.1^{a}$ \\
\hline Phenanthrene & $15.5 \pm 4.4^{\mathrm{a}}$ & $1.0 \pm 0.3^{\mathrm{a}}$ & $0.13 \pm 0.04^{a}$ & $57.6 \pm 5.1^{\mathrm{a}}$ & $3.8 \pm 0.6^{a}$ & $0.73 \pm 0.2^{a}$ \\
\hline Phenanthrene+Cd & $16.2 \pm 10.8^{\mathrm{a}}$ & $1.0 \pm 0.9^{\mathrm{a}}$ & $0.11 \pm 0.09^{\mathrm{a}}$ & $48.8 \pm 6.7^{\mathrm{a}}$ & $3.4 \pm 0.8^{\mathrm{a}}$ & $0.65 \pm 0.1^{a}$ \\
\hline \multicolumn{7}{|l|}{ Siam weed } \\
\hline Unspiked soil & $52.7 \pm 5.0^{\mathrm{a}}$ & $28.1 \pm 6.5^{\mathrm{a}}$ & $11.5 \pm 2.1^{\mathrm{a}}$ & $52.0 \pm 9.9^{\mathrm{a}}$ & $22.9 \pm 1.2^{\mathrm{a}}$ & $5.61 \pm 1.4^{\mathrm{a}}$ \\
\hline Phenanthrene & $45.0 \pm 2.3^{\mathrm{a}}$ & $32.9 \pm 2.1^{\mathrm{a}}$ & $11.4 \pm 2.2^{\mathrm{a}}$ & $36.8 \pm 5.8^{\mathrm{a}}$ & $10.3 \pm 1.6^{b}$ & $1.76 \pm 0.2^{b}$ \\
\hline Phenanthrene+Cd & $40.8 \pm 4.4^{\mathrm{a}}$ & $12.6 \pm 4.0^{b}$ & $3.8 \pm 1.5^{\mathrm{b}}$ & $48.3 \pm 0.9^{\mathrm{a}}$ & $14.0 \pm 3.8^{b}$ & $2.39 \pm 0.8^{b}$ \\
\hline \multicolumn{7}{|l|}{ Winged bean } \\
\hline Unspiked soil & $40.7 \pm 3.3^{\mathrm{a}}$ & $1.6 \pm 0.1^{a}$ & $0.23 \pm 0.01^{\mathrm{a}}$ & $59.0 \pm 5.2^{\mathrm{a}}$ & $1.5 \pm 0.3^{\mathrm{a}}$ & $0.28 \pm 0.0^{\mathrm{a}}$ \\
\hline Phenanthrene & $55.1 \pm 10.7^{\mathrm{a}}$ & $1.6 \pm 0.3^{\mathrm{a}}$ & $0.25 \pm 0.06^{a}$ & $56.9 \pm 9.7^{\mathrm{a}}$ & $1.2 \pm 0.1^{a}$ & $0.35 \pm 0.1^{a}$ \\
\hline Phenanthrene+Cd & $48.7 \pm 9.9^{\mathrm{a}}$ & $1.0 \pm 0.2^{\mathrm{a}}$ & $0.25 \pm 0.06^{\mathrm{a}}$ & $61.4 \pm 9.3^{\mathrm{a}}$ & $1.8 \pm 0.5^{\mathrm{a}}$ & $0.44 \pm 0.1^{\mathrm{a}}$ \\
\hline
\end{tabular}

Different lower case letter denote significant difference $(p<0.05)$ between the same plant in the same column 
Table 2: Root growth parameters of three plants grown in soil spiked with phenanthrene or phenanthrene plus cadmium for 60 days

\begin{tabular}{|c|c|c|c|c|c|c|}
\hline \multirow[t]{2}{*}{ Plant } & \multicolumn{3}{|c|}{ Day 30} & \multicolumn{3}{|c|}{ Day 60} \\
\hline & $\begin{array}{l}\text { Root length } \\
(\mathrm{cm})\end{array}$ & $\begin{array}{l}\text { Root fresh weight } \\
\text { (g) }\end{array}$ & $\begin{array}{l}\text { Root dry weight } \\
\text { (g) }\end{array}$ & $\begin{array}{l}\text { Root length } \\
(\mathrm{cm})\end{array}$ & $\begin{array}{l}\text { Root fresh weight } \\
\text { (g) }\end{array}$ & $\begin{array}{l}\text { Root dry weight } \\
\text { (g) }\end{array}$ \\
\hline \multicolumn{7}{|l|}{ Carpet grass } \\
\hline Unspiked soil & $8.7 \pm 1.1^{\mathrm{a}}$ & $0.1 \pm 0.0^{\mathrm{a}}$ & $0.05 \pm 0.01^{\mathrm{a}}$ & $15.5 \pm 3.1^{\mathrm{a}}$ & $0.4 \pm 0.0^{\mathrm{a}}$ & $0.05 \pm 0.0^{\mathrm{a}}$ \\
\hline Phenanthrene & $7.2 \pm 1.0^{\mathrm{a}}$ & $0.3 \pm 0.0^{\mathrm{a}}$ & $0.05 \pm 0.01^{\mathrm{a}}$ & $18.2 \pm 0.5^{\mathrm{a}}$ & $0.6 \pm 0.2^{\mathrm{a}}$ & $0.09 \pm 0.0^{\mathrm{a}}$ \\
\hline Phenanthrene+Cd & $7.2 \pm 1.8^{a}$ & $0.1 \pm 0.0^{\mathrm{a}}$ & $0.05 \pm 0.01^{\mathrm{a}}$ & $15.8 \pm 2.7^{\mathrm{a}}$ & $0.3 \pm 0.1^{a}$ & $0.06 \pm 0.0^{\mathrm{a}}$ \\
\hline \multicolumn{7}{|l|}{ Siam weed } \\
\hline Unspiked soil & $9.1 \pm 2.4^{\mathrm{a}}$ & $0.2 \pm 0.1^{a}$ & $0.10 \pm 0.07^{\mathrm{a}}$ & $8.7 \pm 3.5^{\mathrm{a}}$ & $1.2 \pm 0.6^{\mathrm{a}}$ & $0.25 \pm 0.1^{a}$ \\
\hline Phenanthrene & $5.1 \pm 1.5^{\mathrm{a}}$ & $0.01 \pm 0.0^{\mathrm{a}}$ & $0.01 \pm 0.00^{\mathrm{a}}$ & $9.8 \pm 2.0^{a}$ & $1.4 \pm 0.7^{\mathrm{a}}$ & $0.14 \pm 0.0^{a}$ \\
\hline Phenanthrene+Cd & $6.3 \pm 0.7^{\mathrm{a}}$ & $0.5 \pm 0.0^{\mathrm{a}}$ & $0.02 \pm 0.01^{\mathrm{a}}$ & $9.3 \pm 3.2^{\mathrm{a}}$ & $1.0 \pm 0.9^{\mathrm{a}}$ & $0.08 \pm 0.0^{6}$ \\
\hline \multicolumn{7}{|l|}{ Winged bean } \\
\hline Unspiked soil & $9.5 \pm 1.3^{\mathrm{a}}$ & $0.4 \pm 0.0^{\mathrm{a}}$ & $0.04 \pm 0.01^{\mathrm{a}}$ & $14.5 \pm 3.4^{\mathrm{a}}$ & $0.6 \pm 0.1^{a}$ & $0.06 \pm 0.0^{\mathrm{a}}$ \\
\hline Phenanthrene & $12.1 \pm 1.3^{\mathrm{a}}$ & $0.5 \pm 0.1^{a}$ & $0.09 \pm 0.02^{\mathrm{a}}$ & $9.9 \pm 1.3^{\mathrm{a}}$ & $0.5 \pm 0.2^{\mathrm{a}}$ & $0.06 \pm 0.0^{a}$ \\
\hline Phenanthrene+Cd & $14.2 \pm 1.6^{a}$ & $0.2 \pm 0.0^{\mathrm{a}}$ & $0.03 \pm 0.01^{\mathrm{a}}$ & $14.9 \pm 1.7^{\mathrm{a}}$ & $0.8 \pm 0.1^{a}$ & $0.08 \pm 0.0^{\mathrm{a}}$ \\
\hline
\end{tabular}

Different lower case letter denote significant difference $(p<0.05)$ between the same plant in the same column

Table 3: Chlorophyll content in leaves of each plant grown in soil spiked with phenanthrene or phenanthrene plus cadmium for 60 days

\begin{tabular}{|c|c|c|c|c|c|c|c|c|}
\hline \multirow[t]{2}{*}{ Plant } & \multicolumn{4}{|c|}{ Day 30} & \multicolumn{4}{|c|}{ Day 60} \\
\hline & $\begin{array}{l}\text { Chlorophyll a } \\
\left(\mathrm{mg} \mathrm{ml}^{-1}\right)\end{array}$ & $\begin{array}{l}\text { Chlorophyll b } \\
\left(\mathrm{mg} \mathrm{ml}^{-1}\right)\end{array}$ & $\begin{array}{l}\text { Total chlorophyll } \\
\left(\mathrm{mg} \mathrm{ml}^{-1}\right)\end{array}$ & a/b ratio & $\begin{array}{l}\text { Chlorophyll a } \\
\left(\mathrm{mg} \mathrm{ml}^{-1}\right)\end{array}$ & $\begin{array}{l}\text { Chlorophyll b } \\
\left(\mathrm{mg} \mathrm{ml}^{-1}\right)\end{array}$ & $\begin{array}{l}\text { Total chlorophyll } \\
\left(\mathrm{mg} \mathrm{ml}^{-1}\right)\end{array}$ & a/b ratio \\
\hline \multicolumn{9}{|c|}{ Carpet grass } \\
\hline C & $28.8 \pm 2.9^{\mathrm{a}}$ & $22.3 \pm 12.7^{\mathrm{a}}$ & $51.1 \pm 15.6^{a}$ & $1.8 \pm 0.9^{a}$ & $20.4 \pm 9.3^{\mathrm{a}}$ & $14.5 \pm 0.3^{\mathrm{a}}$ & $34.9 \pm 9.2^{\mathrm{a}}$ & $1.4 \pm 0.6^{a}$ \\
\hline Phe & $31.8 \pm 0.4^{a}$ & $22.7 \pm 0.1^{\mathrm{a}}$ & $54.5 \pm 0.3^{\mathrm{a}}$ & $1.4 \pm 0.0^{a}$ & $15.2 \pm 1.2^{\mathrm{a}}$ & $19.0 \pm 4.9^{\mathrm{a}}$ & $34.2 \pm 5.1^{\mathrm{a}}$ & $0.9 \pm 0.2^{\mathrm{a}}$ \\
\hline Phe $+C d$ & $31.5 \pm 0.4^{\mathrm{a}}$ & $26.0 \pm 0.9^{a}$ & $57.5 \pm 1.3^{\mathrm{a}}$ & $1.2 \pm 0.0^{a}$ & $21.8 \pm 1.7^{\mathrm{a}}$ & $22.8 \pm 5.6^{a}$ & $44.6 \pm 7.3^{\mathrm{a}}$ & $1.0 \pm 0.2^{\mathrm{a}}$ \\
\hline \multicolumn{9}{|c|}{ Siam weed } \\
\hline C & $30.0 \pm 0.7^{\mathrm{a}}$ & $13.2 \pm 1.4^{\mathrm{a}}$ & $43.2 \pm 2.1^{\mathrm{a}}$ & $2.3 \pm 0.3^{\mathrm{a}}$ & $22.7 \pm 5.5^{\mathrm{a}}$ & $9.9 \pm 3.0^{\mathrm{a}}$ & $32.7 \pm 8.6^{\mathrm{a}}$ & $2.4 \pm 0.2^{\mathrm{a}}$ \\
\hline Phe & $29.4 \pm 2.7^{\mathrm{a}}$ & $17.6 \pm 5.3^{\mathrm{a}}$ & $47.0 \pm 7.7^{\mathrm{a}}$ & $1.9 \pm 0.4^{\mathrm{a}}$ & $22.3 \pm 2.1^{\mathrm{a}}$ & $9.4 \pm 1.0^{\mathrm{a}}$ & $31.8 \pm 3.1^{\mathrm{a}}$ & $2.4 \pm 0.0^{a}$ \\
\hline Phe+Cd & $20.5 \pm 8.2^{\mathrm{a}}$ & $11.6 \pm 5.9^{\mathrm{a}}$ & $32.1 \pm 13.8^{\mathrm{a}}$ & $2.0 \pm 0.3^{\mathrm{a}}$ & $19.3 \pm 1.8^{\mathrm{a}}$ & $8.0 \pm 0.9^{\mathrm{a}}$ & $28.3 \pm 2.7^{\mathrm{a}}$ & $2.4 \pm 0.0^{\mathrm{a}}$ \\
\hline \multicolumn{9}{|c|}{ Winged bean } \\
\hline C & $23.3 \pm 5.7^{\mathrm{a}}$ & $38.0 \pm 10.4^{a}$ & $61.2 \pm 16.1^{a}$ & $0.6 \pm 0.0^{a}$ & $13.2 \pm 1.2^{\mathrm{a}}$ & $18.8 \pm 3.0^{\mathrm{a}}$ & $32.0 \pm 2.2^{\mathrm{a}}$ & $0.8 \pm 0.2^{\mathrm{a}}$ \\
\hline Phe & $23.2 \pm 5.7^{\mathrm{a}}$ & $37.9 \pm 10.5^{\mathrm{a}}$ & $61.2 \pm 16.2^{\mathrm{a}}$ & $0.6 \pm 0.0^{a}$ & $12.7 \pm 1.9^{\mathrm{a}}$ & $19.9 \pm 3.4^{a}$ & $32.6 \pm 2.3^{\mathrm{a}}$ & $0.7 \pm 0.2^{a}$ \\
\hline $\mathrm{Phe}+\mathrm{Cd}$ & $23.1 \pm 5.6^{\mathrm{a}}$ & $37.9 \pm 0.4^{\mathrm{a}}$ & $61.0 \pm 16.1^{\mathrm{a}}$ & $0.6 \pm 0.0^{\mathrm{a}}$ & $6.5 \pm 3.1^{\mathrm{a}}$ & $22.4 \pm 10.1^{\mathrm{a}}$ & $28.9 \pm 10.4^{a}$ & $0.4 \pm 0.2^{\mathrm{a}}$ \\
\hline
\end{tabular}

Different lower case letter denote significant difference $(p<0.05)$ between the same plant in the same column. Abbrevation; Phe $=P h e n a n t h r e n e ; C=$ Unspiked soil

remaining in soil ranged from $4.7-8.1 \mathrm{mg} \mathrm{kg}^{-1}$ dry soil in unplanted soil and soil planted with the test plants on day 60 (Table 5). This suggests that phytostimulation may be the mechanism by which phenanthrene was removed from soil, as have been reported for $\mathrm{PAH}$ removal by other plants in slightly alkaline soil without (Liu et al., 2013) or with some metal (zinc, cadmium and lead) cocontaminants (Wang et al., 2014).

The presence of cadmium at the concentration tested did not inhibit phenanthrene removal in planted alkaline soil. The results also showed that cadmium were not accumulated by these plants. Low concentration of phenanthrene was detected in whole plant biomass. The amount of phenanthrene found in Siam weed and winged bean plants grown in soil without cadmium addition were only 15 and $17 \mu \mathrm{g} \mathrm{g}^{-1} \mathrm{~d}$.wt. of plant biomass. Carpet grass accumulated 49 and $19.1 \mu^{-1}$ g phenanthrene in its biomass when grown in soil without cadmium and soil spiked with cadmium, respectively (Table 6). These were higher than the other two plants. This result is not surprising for winged bean because to our knowledge, this plant has not been reported to be capable of metal accumulation. The results showed that winged bean can survive in soil spiked with phenanthrene+cadmium for 60 days. A previous study also showed that this plant can remove other PAHs such as anthracene and fluorene from alkaline soil 
Table 4: Percentage of phenanthrene remaining in soil spiked with phenanthrene or phenanthrene plus cadmium and planted with carpet grass, Siam weed and winged bean for 60 days

\begin{tabular}{lcc}
\hline Plant & \multicolumn{2}{c}{ Percentage } \\
\cline { 2 - 3 } & \multicolumn{1}{c}{ Day 30} & Day 60 \\
\hline Phenanthrene-spiked soil & \\
No plant & $97.6 \pm 10.5^{\mathrm{a}}$ & $52.1 \pm 3.7^{\mathrm{a}}$ \\
Carpet grass & $59.0 \pm 21.5^{\mathrm{ab}}$ & $6.6 \pm 0.8^{\mathrm{b}}$ \\
Siam weed & $45.5 \pm 6.3^{\mathrm{b}}$ & $6.3 \pm 0.6^{\mathrm{b}}$ \\
Winged bean & $7.9 \pm 4.1^{\mathrm{c}}$ & $12.4 \pm 3.9^{\mathrm{b}}$ \\
Phenanthrene+cadmium (II)-spiked soil & \\
No plant+Cd & $60.9 \pm 13.1^{\mathrm{a}}$ & $18.9 \pm 12.9^{\mathrm{a}}$ \\
Carpetgrass+Cd & $35.5 \pm 3.3^{\mathrm{b}}$ & $27.1 \pm 10.6^{\mathrm{a}}$ \\
Siam weed $+\mathrm{Cd}$ & $31.4 \pm 7.8^{\mathrm{b}}$ & $13.2 \pm 5.7^{\mathrm{a}}$ \\
Winged bean $+\mathrm{Cd}$ & $23.8 \pm 2.6^{\mathrm{b}}$ & $5.1 \pm 2.5^{\mathrm{a}}$ \\
\hline
\end{tabular}

The initial phenanthrene concentration in soil was 87.8 and $44.9 \mathrm{mg} \mathrm{kg}^{-1}$ in soil without and with $\mathrm{Cd}$, respectively, and the initial concentration of cadmium (where relevant) was $6.2 \mathrm{mg} \mathrm{kg}^{-1}$; Different lower case letter denote significant difference $(p<0.05)$ between the same plant in the same column

Table 5: Amount of cadmium remaining in soil and accumulation of cadmium in tissues of plant grown in soil spiked with phenanthrene plus cadmium for 60 days

\begin{tabular}{ll}
\hline Treatment & $\mathrm{Cd}\left(\mathrm{mg} \mathrm{kg}^{-1}\right)$ \\
\hline Unplanted soil & $8.1 \pm 0.8^{\mathrm{a}}$ \\
Soil planted with carpet grass & $7.5 \pm 3.3^{\mathrm{a}}$ \\
Soil planted with Siam weed & $4.7 \pm 0.4^{\mathrm{a}}$ \\
Soil planted with winged bean & $6.0 \pm 3.6^{\mathrm{a}}$ \\
Biomass of carpet grass & B.D. \\
Biomass of Siam weed & 1.0 \\
Biomass of winged bean & 1.2 \\
\hline
\end{tabular}

B.D. = below detection limit; the initial cadmium concentration found in soil was $6.2 \mathrm{mg} \mathrm{kg}^{-1}$

Table 6: Phenanthrene accumulated in tissues of each plant grown in soil spiked with phenanthrene or phenanthrene plus cadmium for 60 days

Plant $\mu \mathrm{g} \mathrm{g}^{-1}$ dry weight whole plant

Soil spiked with phenanthrene

$\begin{array}{ll}\text { Carpet grass } & 49.0 \\ \text { Siam weed } & 15.0 \\ \text { Winged bean } & 17.0\end{array}$

Soil spiked with phenanthrene+ cadmium

Carpetgrass $\quad 19.1$

Siam weed $\quad 17.0$

Winged bean $\quad 17.0$

(pH 8.1) (Somtrakoon et al., 2014 b). Negligible amount of cadmium was accumulated by Siam weed and carpet grass in this study, in contrast to other studies which reported the ability of Siam weed(Phaenark et al., 2009; Tanhan et al., 2007) and carpet grass (Sao et al., 2006) to accumulate cadmium. However, in the earlier studies, Siam weed and carpet grass were planted in soil with lower $\mathrm{pH}$ as compared to the present study. Phaenark et al. (2009) reported that Siam weed was grown in soil ( $\mathrm{pH}$ range 7.057.85) contaminated with zinc and cadmium. The plant was reported to accumulate cadmium in their shoot to the levels exceeding $100 \mathrm{mg} \mathrm{kg}^{-1}$ d.wt. Siam weed grown in Hoagland's solution ( $\mathrm{pH} \mathrm{5.5)} \mathrm{containing} 5 \mathrm{mg} \mathrm{l}^{-1}$ of cadmium $\left(\mathrm{CdSO}_{4}\right)$ for 15 days accumulated 0.10 and $1.44 \mathrm{~g}$ of cadmium per $\mathrm{kg} \mathrm{d}$. wt. in the shoot and root, respectively (Tanhan et al., 2007) while Siam weed planted in a cadmium-contaminated agricultural field in the Mae Sot district (Tak province, Thailand) was reported to accumulate only $4.3 \mathrm{mg}$ and $2.8 \mathrm{mg}$ of cadmium per $\mathrm{kg}$ of shoot and root, respectively (Khaokaew and Landrot, 2015). As for carpet grass, this plant was reported to accumulate cadmium when grown in zinc- and cadmium-contaminated soil $(\mathrm{pH} 5.5$ 6.5). The amount of cadmium found in the shoot and root of carpet grass were 669 and $1965 \mathrm{mg} \mathrm{kg}^{-1} \mathrm{~d}$. wt., respectively, on day 30 of experiment (Sao et al., 2006). They also reported that small amount of cadmium was accumulated in both Siam weed and carpetgrass.

In the current study, the amount of cadmium accumulated by Siam weed and carpet grass was lower than all the previous studies mentioned above. The previous studies measured cadmium accumulation in hydroponic solutions or in soil with lower $\mathrm{pH}$ than the current study. In contrast, the soil used in the current study was alkaline $(\mathrm{pH} 8.9)$ and the $\mathrm{pH}$ of soil after cadmium addition was about $0.1 \mathrm{pH}$ unit below the initial soil $\mathrm{pH}$. It is likely that the alkalinity of soil decreased the bioavailability of cadmium to the tested plants. In support of this view, Yanai et al. (2006) reported that higher $\mathrm{pH}(\mathrm{pH}>6)$ resulted in lower cadmium bioavailability in soil and led to decreasing cadmium accumulation by the hyperaccumulator plant Thlaspi caerulescens.

In summary, winged bean was found to accelerate phenanthrene removal more than the other two plants on day 30. By day 60, all planted treatments showed comparable phenanthrene removal. The main mechanism of phenanthrene removal in this study may be phytostimulation. The alkalinity of soil used in this study likely reduced cadmium accumulation in plant biomass in alkaline soil (Yanai, 2006).

\section{Acknowledgments}

The authors acknowledge the financial support from the Faculty of Science, Mahasarakham University, Thailand (Financial Year 2017) and Mahasarakham University Development Fund. We would like to thank Prof. Hung Lee, School of Environmental Sciences, University of Guelph, Guelph, Ontario, Canada for his helpful advice in preparing and English correcting of this manuscript. 


\section{References}

Anh, B.T., D.D. Kim, P. Kuschk, T.V. Tua, N.T. Hue and N.N. Minh: Effect of soil $\mathrm{pH}$ on As hyperaccumulation capacity in fern species, Pityrogramma calomelanos. J. Environ. Biol., 34, 237-242 (2013).

Anderson, A. and K.O. Nilsson: Influence of lime and soil pH on Cd availability to plants. Ambio., 3, 198-200 (1974).

Bentancur-Galvis, L.A., D. Alvarez-Bernal, A.C. Ramos-Valdivia and L. Dendooven: Bioremediation of polycyclic aromatic hydrocarboncontaminated saline alkaline soils of the former Lake Texcoco. Chemosphere, 62, 1749-1760 (2006).

Hu, Y., Z. Nan, J. Su and N. Wang: Heavy metal accumulation by poplar in calcareous soil with various degrees of multi-metal contamination: Implications for phytoextraction and phytostabilization. Environ. Sci. Pollut. R., 20, 7194-7203 (2013).

Huang, X.D., Y. El-Alawi, D.M. Penrose, B.R. Glick and B.M. Greenberg. Responses of three grass species to creosote during phytoremediation. Environ. Pollut., 130, 453-463 (2004).

Hussain, K., M. Rahman, A. Prakash and R.R. Hoque: Street dust bound PAHs, carbon and heavy metals in Guwahati city-seasonality, toxicity and sources. Sustain. Cities. Soc., 19, 17-25(2015).

Jampasri, K., P. Pokethitiyook, M. Kruatrachue, P. Ounjai and A. Kumsopa: Phytoremediation of fuel oil and lead co-contaminated soil by Chromolaena odorata in association with Micrococcus luteus. Int. J. Phytoremediat., 18, 994-1001 (2016).

Ke, L., T.W.Y. Wong, A.H.Y. Wong, Y.S. Wong and N.F.Y. Tam: Negative effect of humic acid addition on phyteoremdiation of pyrenecontaminated sediment by mangrove seedlings. Chemosphere, 53, 1581-1591 (2003).

Khaokaew, S. and G. Landrot: A field-scale study of cadmium phytoremediation in a contaminated agricultural soil at Mae Sot District, Tak Province, Thailand: (1) Determination of Cdhyperaccumulating plants. Chemosphere, 138, 883-887 (2015).

Kuppusamy, S., P. Thavamani, M. Megharaj, K. Venkateswarlu, Y.B. Lee and R. Naidu: Pyrosequencing analysis of bacterial diversity in soils contaminated long-term with PAHs and heavy metals: Implications to bioremediation. J. Hazard. Mater., 317, 169-79 (2016).

Land Development Department, Thailand. Work manual for soil, water and plant analysis, Document NO: OSD-05. [accessed 2017 January 11]. Available on http://www.ldd.go.th/PMQA /2553/Manual/OSD-05.pdf(2010).

Liu, R., N. Xiao, S. Wei, L. Zhao and J. An: Rhizosphere effects of PAHcontaminated soil phytoremediation using a special plant named Fire Phoenix. Sci. Total Environ., 473-474, 350-358 (2014).

Lyons, B.P., J.L. Barber, H.S. Rumney, T.P.C. Bolam, P. Bersuder, R.J. Law, C. Mason and A.J. Smith, S. Morris, M.J. Devlin, M. Al-Enezi, M.S. Massoud, A.S. Al-Zaidan and H.A. Al-Sarawi: Baseline survey of marine sediments collected from the State of Kuwait: PAHs, PCBs, brominated flame retardants and metal contamination. Mar. Pollut. Bull.,100, 629-636 (2015).

McBride, M.B.: Cadmium uptake by crops estimated from soil total $\mathrm{Cd}$ and pH. Soil Sci., 167, 62-67 (2002).

National Park Board, Singapore. Psophocarpus tetragonolobus (L.) DC. [accessed 2017 May 24]. Available on https://florafaunaweb. nparks gov.sg/special-pages/plant-detail.aspx?id=3335 (2013).

Phaenark, C., P. Pokethitiyook, M. Kruatrachue and C. Ngernsansaruay:
$\mathrm{Cd}$ and $\mathrm{Zn}$ accumulation in plants from the Padaeng zinc mine area. Int. J. Phytoremediat., 11, 479-495 (2009).

Rachwał, M., T. Magiera and M. Wawer: Coke industry and steel metallurgy as the source of soil contamination by technogenic magnetic particles, heavy metals and polycyclic aromatic hydrocarbons. Chemosphere, 138, 863-873 (2015).

Sao, V., W. Nakbanpote and P. Thiravetyan: Cadmium accumulation by Axonopus compressus (Sw.) P. Beauv and Cyperus rotundas Linn growing in cadmium solution and cadmium-zinc contaminated soil. Songklanakarin J. Sci. Technol., 29, 881-892 (2006).

Shahsavari, E., E.M. Adetutu, M. Taha and A.S. Ball: Rhizoremediation of phenanthrene and pyrene contaminated soil using wheat. J. Environ. Manage., 155, 171-176 (2015).

Somtrakoon, K., W. Chouychai and H. Lee: Phytoremediation of anthracene and fluoranthene co-contaminated soils by Luffa acutangula. Maejo Int. J. Sci. Technol., 8, 221-231 (2014a).

Somtrakoon, K., W. Chouychai and H. Lee: Comparing anthracene and fluorene degradation in anthracene and fluorene-contaminated soil by single and mixed plant cultivation. Int. J. Phytoremediat.,16, 415-428 (2014b).

Somtrakoon, K., W. Chouychai and H. Lee: Removal of anthracene and fluoranthene by waxy corn, long bean and okra in leadcontaminated soil. B. Environ. Contam. Tox., 95, 407-413 (2015).

Srithawat Na Ayuthaya, S.: Determination of soil quality in aspect of soil mechanics in soil series in Thailand: Document NO: 380. [accessed 2017 May 20]. Available on http://oss101.ldd.go.th/ osr_data\&service/document/380_soilmechanic.pdf(1995).

Subramanian, A., T. Kunisue and S. Tanabe: Recent status of organohalogens, heavy metals and PAHs pollution in specific locations in India. Chemosphere, 137, 122-134 (2015).

Tanhan, P., M. Krustrachue, P. Pokethitiyook and R. Chaiyarat: Uptake and accumulation of cadmium, lead and zinc by Siam weed (Chromolaena odorata (L.) King and Robinson). Chemosphere, 68, 323-329 (2007).

Tejeda-Agredano, M.C., S. Gallego, J. Vila, M. Grifoll, J.J. Ortega-Calvo and M. Cantos: Influence of the sunflower rhizosphere on the biodegradation of PAHs in soil. Soil Biol. Biochem., 57, 830-840 (2013).

Wang, K., H. Huang, Z. Zhu, T. Li, Z. He, X. Yang and A. Alva: Phytoextraction of metals and rhizoremediation of PAHs in cocontaminated soil by co-planting of Sedum alfredii with ryegrass (Lolium perenne) or castor (Ricinus communis). Int. J. Phytoremediat., 15, 283-298(2013).

Waranusantigul, P., M. Kruatrachue, P. Pokethitiyook and C. Auesukaree: Evaluation of $\mathrm{Pb}$ phytoremediation potential in Buddleja asiatica and B. paniculata. Water Air Soil Poll., 193, 79-90 (2008).

Willscher, S., L. Jablonski, Z. Fona, R. Rahmi and J. Wittig: Phytoremediation experiments with Helianthus tuberosus under different $\mathrm{pH}$ and heavy metal soil concentrations. Hydrometallurgy, 168, 153-158 (2017).

Xiao, N., R. Liu, C. Jin and Y. Dai: Efficiency of five ornamental plant species in the phytoremediation of polycyclic aromatic hydrocarbon (PAH)-contaminated soil. Ecol. Eng., 75, 384-391 (2015).

Yanai, J., F.J. Zhao, S.P. McGrath and P. Kosaki: Effect of soil characteristics on $\mathrm{Cd}$ uptake by the hyperaccumulator Thlaspi caerulescens. Environ. Pollut., 139, 167-175(2006). 